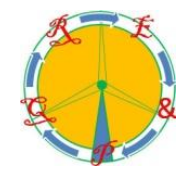

\title{
Territorial management for an appropriate technological choice: the case of CIH and CIBiogás projects in Parana 3 River Basin, Parana, Brazil
}

\author{
M. V. Lange ${ }^{1}$, S. M. Andersen ${ }^{2}$ and J.C. Pasqual ${ }^{3}$ \\ ${ }^{1} \mathrm{PhD}$ student at the Environment and Development Post-Graduate Programme, in the Federal University of Parana \\ Sector of Agricultural Sciences - Rua dos Funcionários 1540, Juveve, Curitiba, Parana, Brazil, CEP: 80035-050 \\ marcelavlange@gmail.com
}

${ }^{2}$ Professor at the Environment and Development Post-Graduate Programme, in the Federal University of Parana Sector of Agricultural Sciences - Rua dos Funcionários 1540, Juveve, Curitiba, Parana, Brazil, CEP: 80035-050 sigridandersen56@gmail.com

${ }^{3} \mathrm{PhD}$ student at the Urban Management Post-Graduate Programme, in the Pontifical Catholic University of Parana. International Hydroinformatics Centre and International Centre for Renewable Energy - Biogas - Av. Tancredo Neves, 6731, Foz do Iguaçu, Parana, CEP: 85856-970. janaina@ maxc.com.br

\begin{abstract}
This paper aims to discuss to what extent the territorial management performed by the International Hydroinformatics Centre and the International Centre for Renewable Energy - Biogas, in partnership with Itaipu Binational, is leading to appropriate technological choice and promoting social change. The assessment is done based on the eleven criteria proposed by Gaudreau, Gibson and Fraser in 2012. Most of the criteria are positively met. The analysed projects seem to contribute in the improvement of society's relationship to energy, going beyond technical and economic concerns to focus on the social and ethical implications of energy strategy. Nonetheless, there is no assessment process implemented, which would allow for personal self-reflection and transformative learning in a more structured way.
\end{abstract}

\section{Key words}

Energy decision-making, Energy planning, Impact assessment, Soft energy path, Renewable sources.

\section{Introduction}

The appropriate technology movement is attributed to the British economist E. F. Schumacher, who wrote several papers since the decade of 1950, which were incorporated into the book "Small is beautiful", first published in 1973. The movement is concerned with the suitability and sustainability of technology for smaller scale setting with a set of characteristic conditions that vary from social factors (human values and needs, technical and managerial skills) to physical environment factors (available materials and energy).

Appropriate technologies foster self-reliance, since they aim to be productive without requiring huge capital investments, offering a possibility to developing countries of relative parity in standard of living without unrealistic investment [1]. They also foster responsibility, given that they are not so elaborated and can be managed for the local population, increasing its control power and knowledge level [1]. In addition, they are less disruptive to the social structure and more adaptable, contributing to the maintenance of cultural diversity [1]. At the same time, appropriate technologies minimize the use of resources and reduce the emissions and wastes, contributing to the environment preservation [1].

A. Lovins [2] drew a soft energy path approach from the appropriate technology movement, linking energy with society. Moving beyond simply measuring efficiency, Lovins warned about the necessity of discussing the utility of energy planning, i.e., its ability to promote and maintain social welfare. Lovins [2] proposed that energy systems should be: based on renewable energy flows; diverse, with each one designed for maximum effectiveness; flexible and low technology so they can be understood and used without esoteric skills; matched in scale and in geographic distribution to end-use needs; and matched in energy quality to end-use needs.

In 2012, Gaudreau, Gibson and Fraser [3], after a discussion on the role of impact assessment in energy decision-making, during the $32^{\text {nd }}$ Annual Meeting of the International Association for Impact Assessment, wrote a paper exploring some aspects of the relationship between energy and society by drawing from the soft energy path and more broadly from studies of socio-technical and socio-ecological systems. They proposed eleven criteria for assessment (which are listed in item 4) that simultaneously inform energy decision-making and attempt to promote social change.

The criteria proposed in the before mentioned paper [3] are used here to assess the energy planning based on territorial management performed by the International Hydroinformatics Centre ( $\mathrm{CIH}$, from the Portuguese denomination Centro Internacional de Hidroinformática) and the International Centre for Renewable Energy Biogas (CIBiogás, from Centro Internacional de Energias Renováveis - Biogás), in partnership with Itaipu Binational, the second biggest hydroelectric plant in the 
world.

There is no attempt here to provide technical information and analysis about the territorial management and the energy projects, since there is plenty literature on that [4][10]. Conversely, the focus is on the often left out social impacts of these projects, paved on a broad understanding of socio-technical and socio-ecological systems.

\section{Itaipu and the pursuit of sustainable development in the Paraná 3 River Basin}

Parana 3 River Basin is a vast region located in western Parana. Paraná is one of 27 federal units of Brazil, located in the southern region of the country. The river basin area comprises about $8,000 \mathrm{~km}^{2}$ and 28 municipalities, being the rivers San Francisco, Guaçu, False San Francisco and Ocoí the main tributaries [11], [12], as shown in figure 1.

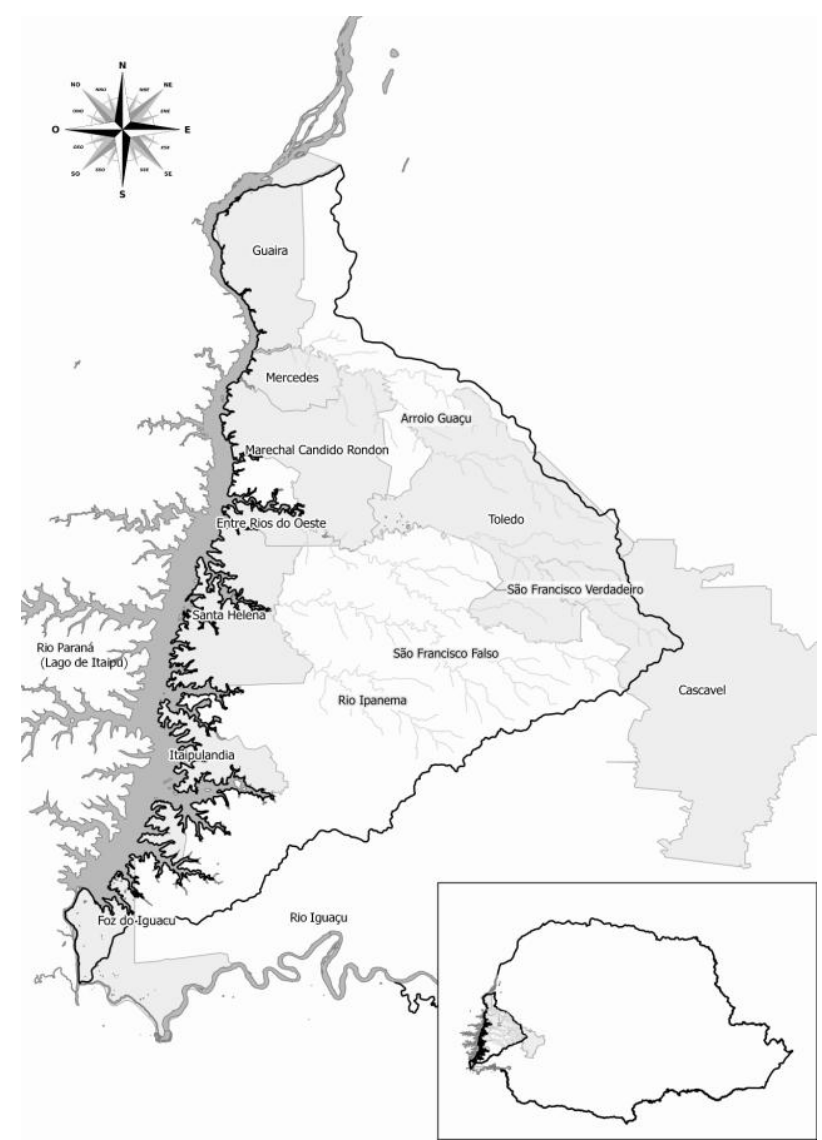

Fig. 1. Parana 3 River: Location and Hydrography (Source: $\mathrm{CIH}$ )

Originally inhabited by Guarani Indians, the region was the stage for the Paraguayan War between 1864 and 1870 [11]. Later, from the 1950s, cultivation of coffee, cotton and sugar cane was intensified. In April 1973, an international agreement between Brazil and Paraguay on the use of water resources of the Parana River led to the construction of Itaipu Binational hydroelectric plant.

The reservoir of Itaipu, with 1,350 square kilometres of flooded area, is located near the confluence of Parana and Iguaçu rivers, occupying the seventh area position in Brazil and providing the best utilization rate of water to produce energy among the big national reservoirs - 10.4 MW per square kilometre [13].
The basin area is rich in biodiversity and natural resources such as water and soil. However, like all agricultural frontier, also suffered the consequences of accelerated deforestation and territorial occupation, occurring with greater intensity from 1950, the result of colonizing initiatives by the state government and agricultural policies in place in the country [12]. Consistent with this history, today the Paraná 3 River Basin land is predominantly occupied by agriculture and animal raising - 92.93\% [12] - and related industrial activities.

Paraná 3 River Basin is located on the left bank of the hydroelectric plant's reservoir, on the Brazilian side and in the area of direct environmental impact of the dam, being the water quality in the basin a major concern since the reservoir formation in 1982. The impacts from expansion of agricultural activities and deforestation of native forests in the region, such as soil erosion, contamination of water bodies with fertilizers, pesticides, domestic and rural effluents and solid waste, were at the origin of this concern. In response, Itaipu established a monitoring water quality programme in the basin.

In this monitoring programme, Itaipu identified a number of problems in the basin, among which were silting - due to deposit of sediments and eroded soil - and eutrophication - due to the input of fertilizers and waste from swine, cattle and poultry farming, agriculture activities and urban population in the region. Itaipu understood that these impacts on the basin and the reservoir could not only harm the hydroelectric power generation and its lifespan, but also the communities around them.

Seeking to deal with this scenario, in 2003, the "Cultivando Água Boa" Programme (Cultivating Good Water Programme) was implemented, from which an extensive movement involving local actors began - Itaipu Binational, community associations, government agencies, NGOs, educational institutions, unions and businesses - in the pursuit of sustainable development in the Paraná 3 River Basin.

\section{The role of Territorial Management for energy planning in the Paraná 3 River Basin}

Due to a change in the mission of Itaipu that occurred in 2003, it was created in the same year the Itaipu Technological Park (PTI, from the Portuguese denomination Parque Tecnológico Itaipu), a scientific and technological centre, based in Brazil and Paraguay, focused on regional development and also the modernization of the hydroelectric plant.

Considering the complex management of the issue of relations between society and the physical environment in river basins, at the time of preparation of the "Cultivando Água Boa" Programme, Itaipu identified the need for adequate information management to enable decision making and planning. For this, it was developed 
the Technical Multipurpose Cadastre (TMC), which was built with the objective of promoting and facilitating the matrix integration of environmental management data with territorial characteristics of real estate properties and river basins [7].

The creation of TMC boosted in 2006 the establishment of $\mathrm{CIH}$, as part of PTI. Resulting from a partnership between the Brazilian and the Paraguayan Governments, the centre is supported by the Unesco International Hydrological Programme. With the mission to develop innovative solutions and Hydroinformatics tools for sustainable management of water resources, the role of $\mathrm{CIH}$ is to converge mediation between research and extension through training and improvements, development of methodologies for territorial management, modelling and applications, communication, exchange of information and promotion of networks.

Through the use of free geoprocessing softwares and geographic information systems (GIS), CIH builds iterative thematic maps in which it can organize and overlap territorial data - potential and viability of energy recovery from water, wind, sunlight and pollution sources with possible energy application - whose integrated analysis allows the action in territorial management.

The environment has several components, which constitute different themes covered in the environmental and energy planning (climate, soils, hydrology, vegetation, land use and occupation, life conditions, economy, among others) [14]. These components are not isolated but respond to distribution patterns and are linked in a complex network of interactions that determine function and behaviour after changes. To better understand these patterns, interactions and functions, the integration of components is a key factor [14], and it is made by $\mathrm{CIH}$ using the territorial dimension as research foundation.

The phenomena related to the components vary constantly in space and time, making difficult to group and process the enormous data quantities which are necessary for a good understanding of their variation [15]. In this context, geotechnologies play an essential role for the researches that intend to understand and demonstrate the spatial and temporal dynamics in environmental and energy planning projects [15]. To integrate the themes through spatial methods, $\mathrm{CIH}$ generates and associates maps, using a computational geoprocessing tool called GIS, which is able to perform overlapping of themes and allow the establishment of numerous types of correlations between them.

In 2008, CIBiogás history has started, with the creation of the Observatory of Renewable Energy for Latin America and the Caribbean. CIBiogás is a scientific, technological and innovation non-profit organization, formed by 17 institutions that develop and/or support renewable energy projects. It aims to promote the sustainable development of the biogas chain and other renewables. CIBiogás is specialized in consulting, knowledge sharing and laboratory analysis in renewable energy, with emphasis on biogas. The institution also promotes the development of projects and public policies related to the theme, in order to encourage the generation of electricity, heat and biofuels in a renewable and sustainable way.

In other words, while $\mathrm{CIH}$ builds the maps with territorial data, CIBiogás uses these maps to promote the sustainable development of the biogas chain and other renewables.

\section{A. Territorial Management in the San Francisco River Sub-Basin}

San Francisco is one of the sub-basins that make up the Paraná 3 River Basin and whose drainage area is the most extensive and representative of the incremental basin of Itaipu hydroelectric plant. The region is specialized in planting soybeans and corn and raising swine, poultry and dairy cattle, high environmental impact activities whose effluent may compromise the water quality of the river and the Itaipu reservoir [4].

\section{1) Ajuricaba Agroenergy Condominium}

$\mathrm{CIH}$ analysed the spatial distribution of information such as livestock, altitude, land use, vegetation, hydrography, and socio-economic indices in the San Francisco River Sub-basin using gvSIG software. The overlap of these maps allowed the identification of potential local biogas generators and areas susceptible to environmental damage as well as areas with agricultural potential for the application of fertilizer [5].

Maps created were made available on the Web Maps System, a tool that allows the simultaneous display of information on a single screen and the creation and storage of geographic data by the user [5]. It was also created the Biogas Geographic Information System (SIGBiogás), a web technology that allows the registration and the location of livestock production units in order to assist technicians in the calculation of biogas production as well as in verifying the technical and economic feasibility of projects. The system also functions as a database with information that may assist in the construction of new research and projects on the water and energy nexus theme.

Based on the information available on the maps, possible arrangements for the potential energy use could be predicted for the region. In 2009, the pilot project Ajuricaba Agroenergy Condominium was started. The project was developed by Itaipu in partnership with other institutions as the National Enterprise Technical Assistance and Rural Extension (EMATER) and the Company of Electric Power of Parana (COPEL).

In the Ajuricaba river micro-basin belonging to the San Francisco sub-basin, the waste generated from agricultural activities are exploited for the production of biogas, which can be transformed into thermal and electrical energy [4]. The project goal is to promote economic, social, environmental and energy sustainability of family farming based on agroenergy. There are 33 properties, with areas between 10 and 20 hectares, which produce soy, corn, wheat, cattle and pigs, generating approximately 16 thousand tons of waste per 
year. 33 digesters were installed for waste degradation [6]. Biogas can be used directly in the properties, to cook food or to heat water for cleaning dairy utensils, or can be sent by pipeline ( $25 \mathrm{~km}$ in total) to a micro- thermal station, in which can be converted into electrical energy, thermal energy and vehicle power.

The Ajuricaba Agroenergy Condominium provides the maintenance of watershed ecosystem by reducing the impact of production activities in the territory and at the same time, safeguards food production and provides energy for regional development.

\section{2) Energy Forests}

The Sustainable Forests project is a partnership between Itaipu and C.Vale, an agribusiness cooperative operating in four Brazilian states, among which is Parana. The project started in 2012 and focuses on the production of wood, an important component of the agribusiness energy matrix. Wood is used in operations with thermal energy, such as grain drying.

The recent increase in agricultural production in western Paraná brought firewood deficit to meet the crop. In some cases, $100 \%$ of the wood used in industrial units is acquired from third parties. In other cases, cooperatives need to purchase firewood at distances greater than 200 $\mathrm{km}$. The transportation cost is inevitably passed on to the cooperating farmers by means of a higher drying cost. This fact exposes the vulnerability of agro-industrial production systems in relation to the energy matrix, mainly related to thermal energy, and brings us to the prospect of a "forestry blackout", where the wood, when available, features such high prices that cripple the business that depends on it.

$\mathrm{CIH}$ mapped the existing forest areas by manual vectorization on Google Earth of the areas identified in a supervised classification performed on Landsat 8 images in the SPRING software version 5.2.6, later validated in field. The maps were generated in gvSIG and QGIS softwares. The areas of forest vocation were set in overlapping layers of soil slope and suitability and soil use and occupation. With the information available on the maps, CIBiogás developed an alternative to decentralize the planting of forests for energy purposes, linking cooperative work, forest vocation land and early clones of eucalyptus, which can be cut earlier (four years).

\section{How close is the territorial management to an appropriate energy planning?}

The following items (A to $\mathrm{K}$ ) show results of the assessment of energy planning based on territorial management performed by $\mathrm{CIH}$ and CIBiogás in Parana 3 river Basin. Each of the items relates to one of the eleven criteria proposed by Gaudreau, Gibson and Fraser [3].

\section{A. Acknowledge problem framing and underlying worldviews}

Itaipu is explicit about its "energy problem" understanding and the deeper worldviews behind it. The water quality in the basin is a major concern for Itaipu since the reservoir formation in 1982, given that the environmental impacts resulting from activities in the region directly affect the energy production in medium to long term. Even so, as the "Cultivando Água Boa" Programme was being developed, more and more actors were involved, and the goal was amplified to the pursuit of sustainable development in the Paraná 3 River Basin, regarding the environment but also the social and economic frameworks, with attention given to the local communities and their development, without forgetting the global perspective of sustainability. The initiative aims to reconcile economic development with energy production and environmental preservation. In this context, CIH has a focus on the water theme and understands it through a broad perspective, involving technology, energy and environment in order to promote progress and innovation in regional, national and international scales. Its projects, actions, obligations and other types of relations are guided by the ethical principles of Itaipu Binational and UNESCO International Hydrological Programme. CIBiogás, in turn, rests on values as cooperation, transparency, commitment, innovation, respect and valuing people to promote the sustainable development of renewable chain.

\section{B. Focus on services, not supply}

$\mathrm{CIH}$ and CIBiogás work on an energy planning which recognizes that energy is a means for social ends, and is valued not for itself, but for the services that it provides. The Ajuricaba Agroenergy Condominium intends to produce biogas to be used by the farmers for cooking, for water heating used to clean dairy utensils, for electrical energy production for self consumption or excess compensation, for thermal energy production used for drying grain, and for vehicle power. The Energy Forests, in turn, provides the small farmers and cooperatives in the region with thermal energy for important activities, as the grain drying. As they turn to be the producers of wood, they became able to control the supply according to the demand, instead of depending on independent producers. Energy produced from biogas and from forest biomass meet end-use demands for these services in a more elegant and non-violent manner than the energy originated from fossil fuels or the external power network.

\section{Promote end-use matching}

The projects result of an energy planning in which the energy supply intends to match the scale and quality of its final use. Regarding the Biogas Condominium, some adaptations were needed for all types of uses. Stoves, for example, had to be adapted in order to use biogas instead of liquefied petroleum gas, through flow and pressure regulation. All technical arrangement in the condominium is innovative, based on production decentralization and use centralization, in order to reduce costs, manpower and space needed and thus make the arrangement viable. A micro thermoelectric central and a grain dryer were built in order to allow the centralized use of biogas. The construction of the structures followed the existing rules for gas pipelines, power plants and boilers, but in parts, technology and methodology had to be developed from scratch. After these arrangements and adaptations, the scale and quality of the energy services is 
as satisfactory as the one from conservative energies used before. Regarding the Energy Forests project, the project is still in the structuring and validation phase. The commercial planting with the proposed methodologies has not started yet. Then, it is still unknown the percentage of the agricultural need that will be supplied by the wood coming from the plated forests. There are some chemical and physical factors of the quality of wood that are affected with early cutting of trees (before age 7), as lignin content and density. However the variation is minimal compared to forest biomass with 2, 3 or 4 years, without major influence on the final product, thermal energy.

\section{Develop energy bridges}

Territorial management performed by $\mathrm{CIH}$ and CIBiogás focus on energy systems as being a constant bridge to more sustainable social structures, recognizing there is no ultimate energy end state. The bridging mechanisms proposed aim to be minimally disruptive, considering the vocations of the region, but require societal and technical change and require seeking and developing means of production that do not (or minimally) rely on fossil fuels.

\section{E. Use energy policy to catalyze broader change in social values}

Territorial management performed by $\mathrm{CIH}$ and CIBiogás recognizes that energy strategy has implications far beyond energy supply and demand, and rather affects a wide variety of sector (e.g. agricultural waste biodigestion improves sanitation, public health, and the environmental quality of the surrounding water bodies). The energy systems are designed as a means of repatterning society in a positive manner: promoting familiar agriculture and energy security, fostering social learning, among others. With the Ajuricaba Agroenergy Condominium, families now have a choice of clean and renewable power generation. Moreover, they have access to a high quality bio-fertilizer to be applied in pastures and crops, increasing productivity and reducing production costs. In addition, the project provided improved quality of the final treated effluent, reducing the incidence of pathogenic vectors and also the smelling caused by manure in the properties, consequently improving local people quality of life. There is also an increase in environmental awareness for locals and people who live in the neighbourhood. One of the main points in the implementation of the Energy Forests project is the diversification of the small farmers' income. The use of forest vocation lands, dense planting and short rotation plantations contributes adding a shortterm source of income. This strategy also helps to develop the sectors of service and supply, generating jobs and income in the project implementation area. As the project is based on areas of cooperative members, they are beneficiated with the inclusion of one more product to be produced with known quality and reliability of supply, thus strengthening the energy security.

\section{F. Prioritize the people and the goods will look after themselves}

Soft energy planning should favour energy technologies and decision-making processes that promote democracy and citizen engagement. The Ajuricaba Agroenergy Condominium boosted the formation of a cooperative among the farmers (Cooperbiogás), for managing the collective production of biogas, which allows their interaction and the discussion of common problems. The Energy Forests project has a constant interaction between the main stakeholders of the project. All information is shared consistently. The main management practices adopted by the project were defined through experiences of farmers, adapted to their realities. Cooperatives operate strategically, in the planning of actions and defining the demand and quality of forest biomass.

\section{G. Promote reciprocity}

Territorial management performed by $\mathrm{CIH}$ and CIBiogás promotes energy technologies that foster greater reciprocity so as to allow people to become more involved in, and aware of, the production, consumption and operation of their energy technologies. The technologies used for biogas utilization are cheap and easy to maintain. Farmers were trained and informed about the functioning of technologies installed in their properties, and rely on the monitoring and tracking of specialized technicians from CIBiogás, who are constantly visiting the properties. In the interest region of the Energy Forests project, the level of experience to commercial high-yield plantations is very low. Some cooperatives have a certain forest planning, but little prepared, with low level of technical support. Thus, there is great difficulty to consolidate forestry, both in cooperatives and producers. The management techniques that are being proposed have some divergent points of common management, mainly on the issue of tillage (sub soiling and spacing) and application of bio-fertilizers. Thus, all technical support development part, for this new management model will be further developed and consolidated.

\section{H. Recognize the cumulative and emergent consequences of mass adoption}

It is recognized that many of the important benefits and drawbacks of these energy technologies emerge during mass adoption. To the extent possible, such cumulative and emergent effects are anticipated and planning is done accordingly. One of the benefits of the biogas technology is a choice opportunity considering the growing demand and prices of fuel and electricity. One of the associated drawbacks of the biogas technology, however, is the allocation of food crop productive areas for biogas production, arising questioning about food security. The entire scope of the project, nevertheless, worries about overcoming this problem relying on biogas production from the processing of waste, i.e. turning environmental liabilities into means of seeking energy sovereignty. Regarding the Energy Forest project, it plans that the effect of the increase of forest plantations for energy purposes will be regulated by the cooperatives. With an appropriate energy planning, it will be possible to regulate the supply and demand balance, based on the production areas of the cooperative, differently from the currently applied dynamics, where supply is controlled by independent producers.

\section{Avoid technological lock-in}

Territorial management performed by $\mathrm{CIH}$ and CIBiogás 
favour energy technologies that maintain and improve the ability of future generations to determine their own desirable socio-technical structure. In the Ajuricaba project, it is always prioritized the use of national materials, equipment and services, or at least of products that are already available in Brazil with accessible maintenance service. When these requirements are not possible to achieve, the development of technologies is boosted, as it could be seen for the vertical biodigestor, the HDPE rural pipeline, and the water filter via scrubbing. All the clones used in the Energy Forests project are highly commercial and developed by domestic companies for energy production. It is predicted a future development of clones adapted to the region and with features that optimize the production of thermal energy.

\section{J. Promote transformative decision-making processes}

The learning of $\mathrm{CIH}$ and CIBiogás is constant. From the time the projects were started, various alignments have been conducted for the planning and execution strategies, always intending to seek for effectiveness of actions taken. Nonetheless, there is no assessment process implemented to facilitate transformative learning.

\section{K. Favour energy systems that promote responsibility}

In both projects, the involvement of farmers and cooperatives in the discussions about the project implementation was extremely healthy, considering that these actions led to a sense of product responsibility with the project, a fact essential for project sustainability. Nonetheless, there is no assessment process implemented to facilitate the return of feedbacks to the decision-makers.

\section{Conclusion and future directions}

The energy planning based on territorial management performed by $\mathrm{CIH}$ and CIBiogás meets most of the criteria proposed by Gaudreau, Gibson and Fraser [3]. The analysed projects seem to contribute in the improvement of society's relationship to energy, going beyond technical and economic concerns to focus on the social and ethical implications of energy strategy.

Nonetheless, there is no assessment process implemented. This would allow for personal self-reflection and transformative learning in a more structured way. The assessment could provide an opportunity for constantly reformulating the energy 'problem', and, to the extent possible, encourage all those involved to change their own actions so as to better reflect our understanding of the problems faced. It would also facilitate the promotion of responsibility, such that feedback about the consequences of decision-making returns to the decision-makers in an appropriate manner, and benefits and risks of decisions are fairly shared. Besides, an assessment process would ensure that all items listed here were constantly being evaluated, so that the compliance was more consistent and embedded. Finally, informing energy decision-making could promote social change and then contribute to a closer approach to the soft energy path.

\section{References}

[1] B. Hazeltine, "Appropriate Technology," in Technology,

Humans, and Society: Toward a Sustainable World, R. C. Dorf, Ed. Academic Press, 2001, pp. 101-107.

[12] UNIOESTE, ITAIPU BINACIONAL, and CBHP3, "Plano da Bacia Hidrográfica do Paraná 3," Cascavel, 2014.

[13] Itaipu Binacional, "Energia: Reservatório,” 2010. [Online]. Available: https://www.itaipu.gov.br/energia/reservatorio. [Accessed: 22-Aug-2015].

[14] R. F. dos Santos, "Integração das informações," in Planejamento Ambiental: teoria e prática, 1st ed., Oficiona de Textos, 2007, pp. 127-150.

[15] A. R. Cardoso, C. Poleto, E. L. da Fonseca, and L. M. W. Ferraro, "Geotecnologias aplicadas em estudos ambientais," in Introdução ao gerenciamento ambiental, Rio de Janeiro: Editora Interciência, 2010, pp. $73-108$. 